\title{
COVID-19 outcomes among hospitalized men with or without exposure to alpha-1-adrenergic
} receptor blocking agents

Shilong Li, $\mathrm{PhD}^{1}$; Tomi Jun, $\mathrm{MD}^{2}$; Zichen Wang, $\mathrm{PhD}^{1}$; Yu-Han Kao, $\mathrm{PhD}^{1}$; Emilio Schadt, $\mathrm{BS}^{1}$; Maximilian F. Konig, $\mathrm{MD}^{3,4}$; Chetan Bettegowda, MD, $\mathrm{PhD}^{3,5}$; Joshua T. Vogelstein, $\mathrm{PhD}^{6,7}$; Nickolas Papadopoulos, $\mathrm{PhD}^{3,8}$; Ramon E. Parsons, MD, $\mathrm{PhD}^{2,10}$; Rong Chen, $\mathrm{PhD}^{1,9}$; Eric E. Schadt, $\mathrm{PhD}^{1,9}$; Li Li, $\mathrm{MD}^{1,9 *}$; William K. Oh, MD $\mathrm{M}^{1,2,10 *}$

${ }^{1}$ Sema4, Stamford, CT, USA.

${ }^{2}$ Division of Hematology \& Medical Oncology, Icahn School of Medicine at Mount Sinai, New York, NY, USA.

${ }^{3}$ Ludwig Center, Lustgarten Laboratory, and the Howard Hughes Medical Institute at The Johns Hopkins Kimmel Cancer Center, Baltimore, MD, USA.

${ }^{4}$ Division of Rheumatology, Department of Medicine, The Johns Hopkins University School of Medicine, Baltimore, MD, USA.

${ }^{5}$ Department of Neurosurgery, The Johns Hopkins University School of Medicine, Baltimore, MD, USA.

${ }^{6}$ Department of Biomedical Engineering, Institute for Computational Medicine, The Johns Hopkins University, Baltimore, MD, USA.

${ }^{7}$ Department of Biostatistics, The Johns Hopkins Bloomberg School of Public Health at The Johns Hopkins University, Baltimore, MD, USA.

${ }^{8}$ Department of Oncology and Pathology, The Johns Hopkins University School of Medicine, Baltimore, MD, USA.

${ }^{9}$ Department of Genetics and Genomic Sciences, The Icahn Institute for Genomics and Multiscale Biology, Icahn School of Medicine at Mount Sinai, New York, NY, USA.

${ }^{10}$ Tisch Cancer Institute, Icahn School of Medicine at Mount Sinai, New York, NY, USA.

*Corresponding author. E-mail: william.oh@sema4.com; 1i.li@sema4.com 
medRxiv preprint doi: https://doi.org/10.1101/2021.04.08.21255148; this version posted April 11, 2021. The copyright holder for this preprint (which was not certified by peer review) is the author/funder, who has granted medRxiv a license to display the preprint in perpetuity.

It is made available under a CC-BY-NC-ND 4.0 International license .

\begin{abstract}
(294 words)
Importance: Alpha-1-adrenergic receptor antagonists ( $\alpha_{1}$-blockers) can abrogate pro-inflammatory cytokines and may improve outcomes among patients with respiratory infections. Repurposing readily available drugs such as $\alpha_{1}$-blockers could augment the medical response to the COVID-19 pandemic.
\end{abstract}

Objective: To evaluate the association between $\alpha_{1}$-blocker exposure and COVID-19 mortality

Design: Real-world evidence study

Setting: Patient level data with 32,355 records tested for SARS-CoV-2 at the Mount Sinai Health System including 8,442 laboratory-confirmed cases extracted from five member hospitals in the New York City metropolitan area.

Participants: 2,627 men aged 45 or older admitted with COVID-19 between February 24 and May 31, 2020

Exposures: $\alpha_{1}$-blocker use as an outpatient or while admitted for COVID-19

Main Outcomes and Measures: In-hospital mortality

Results: Men exposed to $\alpha_{1}$-blockers $(\mathrm{N}=436)$ were older (median age 73 vs. 64 years, $\mathrm{P}<0.001$ ) and more likely to have comorbidities than unexposed men $(\mathrm{N}=2,191)$. Overall, 758 (28.9\%) patients died in hospital, 1,589 (60.5\%) were discharged, and 280 (10.7\%) were still hospitalized as of May 31, 2020. Outpatient exposure to $\alpha_{1}$-blockers was not associated with COVID-19 hospital outcomes, though there was a trend towards significance (OR 0.749, 95\% CI 0.527-1.064; $\mathrm{P}=0.106)$. Conversely, inpatient use of $\alpha_{1}$-blockers was independently associated with improved in-hospital mortality in both multivariable logistic (OR 0.633, 95\% CI 0.434-0.921; $\mathrm{P}=0.017$ ) and Cox regression analyses (HR 0.721, 95\% CI 0.572-0.908; $\mathrm{P}=0.006$ ) adjusting for patient demographics, comorbidities, and baseline vitals and labs. Age-stratified analyses suggested greater benefit from inpatient $\alpha_{1}$-blocker use among younger age groups: Age 45-65 OR 0.384, 95\% CI 0.164-0.896 ( $\mathrm{P}=0.027$ ); Age 55-75 OR 0.511, 95\% CI 0.297-0.880 $(\mathrm{P}=0.015)$; Age 65-89 OR 0.810, 95\% CI 0.509-1.289 ( $\mathrm{P}=0.374)$.

Conclusions and Relevance: Inpatient $\alpha_{1}$-blocker use was independently associated with improved COVID-19 mortality among hospitalized men. Clinical trials to assess the therapeutic value of $\alpha_{1}$ blockers in COVID-19 are warranted. 
medRxiv preprint doi: https://doi.org/10.1101/2021.04.08.21255148; this version posted April 11, 2021. The copyright holder for this preprint (which was not certified by peer review) is the author/funder, who has granted medRxiv a license to display the preprint in perpetuity.

It is made available under a CC-BY-NC-ND 4.0 International license .

\section{Introduction}

Severe coronavirus disease 2019 (COVID-19) has been linked to dysregulated immune responses, including an overexuberant inflammatory response marked by high levels of proinflammatory cytokines such as interleukin-6 (IL-6). ${ }^{1,2}$ Immunosuppressive drugs such as glucocorticoids have become a standard component of treatment for severe COVID- $19,{ }^{3}$ and several trials of anti-cytokine or anti-inflammatory agents are underway or have reported promising results. ${ }^{4-10}$ Despite these advances, there remains a pressing need for safe, effective, and widely available therapeutic options.

Adrenergic signaling has been linked to hyperinflammation in models of bacterial sepsis and cytokine release syndrome. In pre-clinical experiments, a positive feedback loop of adrenergic signaling was identified wherein macrophages responded to catecholamines by producing more catecholamines and inflammatory cytokines; this adrenergic loop could be interrupted by blockade of $\alpha_{1}$-adrenergic receptors with prazosin. ${ }^{11}$ In a retrospective clinical study of patients with acute respiratory distress and pneumonia, exposure to $\alpha_{1}$-adrenergic receptor antagonists ( $\alpha_{1}$-blockers) was associated with a significant reduction in risk of mechanical ventilation or death. ${ }^{12}$ Similarly, a recent retrospective analysis of 25,130 patients with COVID-19 across the United States Veterans Health Administration hospital system showed that outpatient exposure to any $\alpha_{1}$-blocker was associated with decreased in-hospital mortality compared to matched controls not on any $\alpha_{1}$-blocker at the time of hospital admission. ${ }^{13}$

These observations have led to the hypothesis that $\alpha_{1}$-blockers in routine clinical use (e.g. prazosin, doxazosin, tamsulosin, etc.) may be repurposed for COVID-19 treatment. ${ }^{14}$ We therefore conducted this real-world evidence study based on electronic medical record (EMR) data to determine whether exposure to $\alpha_{1}$-blockers is independently associated with mortality among patients hospitalized with COVID-19.

\section{Methods}

\section{Data sources}

This retrospective study utilized de-identified electronic medical record (EMR; Epic systems, Verona, WI) data from 5 member hospitals within the Mount Sinai Health System (MSHS) in the New York City metropolitan area. De-identified EMR data were obtained via the Mount Sinai Data Warehouse (https://labs.icahn.mssm.edu/msdw/). We identified 8,442 MSHS patients with PCR confirmed diagnosis of COVID-19 from February 24 through May 31, 2020 during the peak of pandemic in NYC. COVID-19 was diagnosed by real-time reverse transcriptase polymerase chain reaction (RT-PCR)-based clinical tests from nasopharyngeal swab specimens. 
medRxiv preprint doi: https://doi.org/10.1101/2021.04.08.21255148; this version posted April 11, 2021. The copyright holder for this preprint (which was not certified by peer review) is the author/funder, who has granted medRxiv a license to display the preprint in perpetuity. It is made available under a CC-BY-NC-ND 4.0 International license .

We retrieved patient demographics, social history, medication history, and disease comorbidities from the EMR including age, gender, race/ethnicity, smoking status, asthma, chronic obstructive pulmonary disease (COPD), hypertension, obstructive sleep apnea, obesity, diabetes, chronic kidney disease, human immunodeficient virus (HIV) infection, cancer, coronary artery disease, atrial fibrillation, heart failure, chronic viral hepatitis, alcoholic nonalcoholic liver disease, and acute kidney injury (AKI). Patients aged $\geq 89$ years were assigned an age of 89 to prevent re-identification. Medications by prescription or hospital administration captured in EMR from January 1, 2019 till May 31, 2020 were included in the medication history. We identified disease comorbidities through their corresponding ICD-10-CM codes before hospital admission and during hospitalization.

We also extracted data from each hospital encounter, including vital sign and laboratory data at the time of presentation, and medications administered during hospitalization. Vital sign and laboratory data extracted included: white blood cell count (WBC), serum creatinine, anion gap, potassium, alanine aminotransferase (ALT), body mass index (BMI), temperature, oxygen saturation, heart rate, respiratory rate, systolic blood pressure (SBP) and diastolic blood pressure (DBP).

We defined three possible outcomes for each hospitalization: in-hospital death (deceased), discharged to home or other locations not associated with acute medical care (recovered), and continued hospitalization (right censored). The duration of hospitalization was calculated from the beginning of the hospital encounter till death or discharge.

This study was approved by the Mount Sinai institutional review board (IRB): IRB-17-01245.

\section{Study design}

This was a retrospective EMR-based study designed to test the independent association of $\alpha_{1}$-blocker exposure with in-hospital death among COVID-19 patients. We first identified 6,218 inpatients positive for COVID-19 in one of 5 hospital systems within the MSHS as of May 31, 2020 (Figure 1). The majority (93\%) of $\alpha_{1}$-blocker users in this cohort were men aged 45 or older. We therefore limited the analysis cohort to men aged 45 or older $(\mathrm{N}=2,627)$.

We defined $\alpha_{1}$-blocker exposure as an active prescription from January 1, 2020 for an $\alpha_{1}$-blocker (tamsulosin, alfuzosin, silodosin, terazosin, doxazosin, and prazosin) up to and including hospitalization for COVID-19 ( $\mathrm{N}=436)$. We further defined a subset of patients $(\mathrm{N}=343)$ with documented $\alpha_{1}$-blocker administration during their hospitalization, which we defined as " $\alpha_{1}$-blocker inpatient use". 
medRxiv preprint doi: https://doi.org/10.1101/2021.04.08.21255148; this version posted April 11, 2021. The copyright holder for this preprint (which was not certified by peer review) is the author/funder, who has granted medRxiv a license to display the preprint in perpetuity.

It is made available under a CC-BY-NC-ND 4.0 International license .

Potential confounders in the analysis included demographic characteristics, comorbidities, baseline labs and vitals, and exposure to medications used to treat hypertension, hyperlipidemia, and inflammation. Detailed medication names included in these categories are shown in supplement Table S1.

\section{Statistical analysis}

Patient characteristics were summarized as median and interquartile range (IQR) for continuous variables or mean and standard deviation (SD). We displayed categorical variables as number and percentage (\%). We performed a statistical test of hypothesis for differences using the Kruskal-Wallis test or two sample ttest for continuous variables, and the $\chi^{2}$ test for categorical variables.

We employed multivariate logistic regression models with potential confounders to estimate the odds ratio and corresponding 95\% confidence interval for COVID-19 in-hospital mortality (deceased=1) versus recovery (recovered $=0$ ) associated with $\alpha_{1}$-blocker use. We considered the following potential confounders: age, hospital stay duration, race, smoking status, BMI, temperature, $\mathrm{O} 2$ saturation, heart rate, respiratory rate, hypertension, asthma, COPD, obstructive sleep apnea, obesity, diabetes mellitus, chronic kidney disease, HIV, cancer, coronary artery disease, atrial fibrillation, heart failure, chronic viral hepatitis, liver disease, AKI, ICU stay, WBC, creatinine, anion gap, potassium, and ALT. We applied the Wald-based power and sample size formulas for logistic regression to calculate the power given the observed sample size. ${ }^{15}$ We used two-tailed test to estimate the probability of event under the null hypothesis which was the in-hospital mortality rate and we used the binomial distribution for $\alpha_{1}$-blocker with the prescription rate as the probability.

To account for right-censored patients $(\mathrm{N}=280)$, we used multivariate Cox proportional hazard models to evaluate the association between $\alpha_{1}$-blockers and survival (in-hospital mortality). We estimated the hazard ratio of $\alpha_{1}$-blockers on COVID-19 patient in-hospital survival, adjusting for the same confounders mentioned above.

We utilized propensity score weighting to adjust the potential confounders between those exposed or unexposed to $\alpha_{1}$-blockers. We utilized the R package 'twang' and calculated the propensity scores based on average treatment effect on the treated (ATT) and Kolmogorov-Smirnov evaluation criterion. We then employed the 'survey' R package by fitting logistic regression models with propensity scores as the weights to assess the $\alpha_{1}$-blocker treatment effect on COVID-19 patients.

Statistical significance was defined as a two-sided P-value $<0.05$, unless otherwise noted.

Sensitivity analysis 
medRxiv preprint doi: https://doi.org/10.1101/2021.04.08.21255148; this version posted April 11, 2021. The copyright holder for this preprint (which was not certified by peer review) is the author/funder, who has granted medRxiv a license to display the preprint in perpetuity. It is made available under a CC-BY-NC-ND 4.0 International license .

To evaluate the robustness of the associations between $\alpha_{1}$-blockers and COVID-19 in-hospital mortality, we performed sensitivity analysis to assess the impact from potential unmeasured or uncontrolled confounding. We calculated E-values for odds and hazard ratios as point estimates, in addition to Evalues for their upper confidence limits. ${ }^{16}$ The point estimates represent the strength of unmeasured or uncontrolled confounding required to explain away the observed associations. The upper limits signify the strength of unmeasured or uncontrolled confounding needed to move the confidence interval to include the null, i.e. $\mathrm{OR}=1$ or $\mathrm{HR}=1$. If the effect of unmeasured or uncontrolled confounding is weaker than the calculated E-value, the association of $\alpha_{1}$-blockers with COVID-19 in-hospital mortality could not be fully biased by a weaker confounder.

\section{Results}

\section{Patient characteristics and outcomes}

We identified 6,218 inpatients positive for COVID-19 admitted to one of 5 hospitals within the MSHS as of May 31, 2020. Among these 6,218 patients, 464 patients (7.5\%) had been prescribed $\alpha_{1}$-blockers between January 1, 2020 up to and including their hospitalization, with at least 2 months prior to admission; most of these patients were men aged 45 or older $(\mathrm{N}=436,93 \%)$. Therefore, we limited the analysis cohort to men aged 45 years or older $(\mathrm{N}=2,627)$. This cohort was divided into an $\alpha_{1}$-blockerexposed group $(\mathrm{N}=436)$ and an unexposed group $(\mathrm{N}=2,191)$. All patients in the $\alpha_{1}$-blocker group had been prescribed $\alpha_{1}$-blockers at some point from January 1, 2020 up to and including their COVID-19 hospitalization (" $\alpha_{1}$-blocker exposure"); a subset of these patients $(\mathrm{N}=343)$ had documented $\alpha_{1}$-blocker administration during their hospitalization ("inpatient $\alpha_{1}$-blocker use").

The $\alpha_{1}$-blocker exposed group was older (median age 73 vs. 64 years, $\mathrm{P}<0.001$ ) and more likely to have comorbidities than the unexposed group. Chronic diseases such as COPD, hypertension, diabetes mellitus, chronic kidney disease, cancer, and cardiovascular disease were significantly enriched in the $\alpha_{1^{-}}$ blocker group. Additional patient demographics for the two groups are shown in Table 1 and Figure S1.

Overall, 758 (28.9\%) patients died, 1,589 (60.5\%) were discharged, and $280(10.7 \%)$ were still hospitalized as of May 31, 2020. Unadjusted in-hospital mortality was 32.3\% in the exposed group and $28.2 \%$ in the unexposed group.

$\alpha_{1}$-blocker exposure and COVID-19 in-hospital mortality

We evaluated the association of $\alpha_{1}$-blockers on COVID-19 patients with known outcomes (death: $\mathrm{N}=758$; discharge: $\mathrm{N}=1,589$ ) using multivariate logistic-regression models. In the overall population, $\alpha_{1}$-blocker exposure was not significantly associated with in-hospital mortality (OR 0.749; 95\% CI, 0.527-1.064; 
medRxiv preprint doi: https://doi.org/10.1101/2021.04.08.21255148; this version posted April 11, 2021. The copyright holder for this preprint (which was not certified by peer review) is the author/funder, who has granted medRxiv a license to display the preprint in perpetuity.

It is made available under a CC-BY-NC-ND 4.0 International license .

$\mathrm{P}=0.106$ ) with the power $\beta=0.62$ based on the sample size of 2347 . There was a trend towards a protective association for $\alpha_{1}$-blocker exposure in the subset of patients who were hospitalized for at least 24 hours, though this was not significant $(\mathrm{N}=2,276$; OR 0.722; 95\% CI, 0.505-1.034; $\mathrm{P}=0.075$ ) (Table 2). This might be due to limited sample size ( $\beta=0.71$ in the Wald-based power analysis).

To account for right-censored patients $(\mathrm{N}=280)$, we used Cox proportional hazard models to evaluate the association of $\alpha_{1}$-blocker exposure and COVID-19 in-hospital survival. There was a trend towards a protective effect of $\alpha_{1}$-blocker exposure in the overall cohort (HR 0.808; 95\% CI, 0.652-1.002; $\mathrm{P}=0.052$ ) and among those hospitalized for at least 24 hours (HR 0.823; 95\% CI, 0.660-1.027; P=0.085), though these associations were not significant (Table 3).

\section{Inpatient $\alpha_{1}$-blocker use and COVID-19 in-hospital mortality}

We further assessed the impact of $\alpha_{1}$-blockers on mortality for patients with documented administration of $\alpha_{1}$-blockers while admitted to the hospital $(\mathrm{N}=343)$ compared to unexposed patients. We observed that inpatient $\alpha_{1}$-blocker use significantly reduced the risk of in-hospital mortality overall (OR $0.633 ; 95 \%$ CI 0.434-0.921; $\mathrm{P}=0.017$ ) and among those hospitalized for at least 24 hours (OR 0.607; 95\% CI, 0.415$0.890 ; \mathrm{P}=0.01)$ (Table 2).

The survival analysis also showed improved in-hospital survival for those with inpatient $\alpha_{1}$-blocker use overall (HR 0.721; 95\% CI, 0.572-0.908; $\mathrm{P}=0.006$ ), and among patients hospitalized for at least 24 hours (HR 0.751; 95\% CI, 0.593-0.950; $\mathrm{P}=0.017$ ) (Table 3).

\section{Sensitivity analysis}

We assessed the impact of potential unmeasured or uncontrolled confounding on the observed associations between inpatient $\alpha_{1}$-blockers use and COVID-19 in-hospital mortality using the E-value metric (Table S2) ${ }^{16}$ Based on this analysis, an unmeasured confounder would have to have an odds ratio of at least 1.25 (in the logistic regression analysis) or a hazard ratio of at least 1.34 (in the survival analysis) to cause the $95 \%$ confidence interval for the treatment effect of inpatient $\alpha_{1}$-blockers use to include the null.

Age-stratified associations of $\alpha_{1}$-blockers and COVID-19 in-hospital mortality

We assessed the interaction between age and inpatient $\alpha_{1}$-blocker use for overall cohort and patients with hospital stay $>1$ day, respectively, and we did not find any significance between the interaction and inhospital mortality. Therefore, to identify differences in the treatment effect of $\alpha_{1}$-blockers on different age groups, we segmented the population into three age groups $(45-65 ; 55-75 ; 65-89)$ and analyzed each 
medRxiv preprint doi: https://doi.org/10.1101/2021.04.08.21255148; this version posted April 11, 2021. The copyright holder for this preprint (which was not certified by peer review) is the author/funder, who has granted medRxiv a license to display the preprint in perpetuity.

It is made available under a CC-BY-NC-ND 4.0 International license .

group separately using logistic regression, adjusting for the same covariates as the unstratified analysis. The age groups were overlapped by 10 years to preserve sample size. Inpatient $\alpha_{1}$-blocker use was associated with a significantly lower risk of in-hospital mortality in the 45-65 (OR 0.384; 95\% CI 0.1640.896; $\mathrm{P}=0.027$ ) and 55-75 age groups (OR 0.511; 95\% CI 0.297-0.880; $\mathrm{P}=0.015)$, but not the 65-89 age group (OR 0.810; 95\% CI 0.509-1.289; $\mathrm{P}=0.374)$ (Table 4).

\section{Propensity score analysis}

We further assessed the effect of $\alpha_{1}$-blockers on in-hospital mortality using propensity-weighted logistic regression. These yielded similar results as the multivariable regression and age-stratified analyses. Inpatient $\alpha_{1}$-blocker use was associated with reduced in-hospital mortality (OR 0.630; 95\% CI 0.4240.935; $\mathrm{P}=0.022)$ whereas $\alpha_{1}$-blocker exposure was not (OR 0.740; 95\% CI 0.512-1.070; $\left.\mathrm{P}=0.110\right)$ (Table S3). In age-stratified analyses, patients in younger age groups had greater benefit from $\alpha_{1}$-blocker exposure and inpatient $\alpha_{1}$-blocker use than patients in the oldest age group (Table 4).

\section{Discussion}

Using a racially and ethnically diverse cohort from New York City comprising 2,627 men aged 45 or older hospitalized COVID-19 patients seen between February 24 and March 31, 2020, we found that inpatient use of $\alpha_{1}$-blockers was significantly associated with reduced in-hospital mortality, whereas outpatient exposures were not associated with benefit, although there was a trend towards significance. In age stratification analysis, we found that $\alpha_{1}$-blocker use was more beneficial to younger age groups.

Drug repurposing is the process of finding new indications for drugs already in clinical use. The appeal of rapidly validating and deploying an existing drug against a deadly global pandemic is clear, especially if the drug is widely available and affordable. Dexamethasone, now a standard in COVID-19 treatment, is an example of a commonly used drug repurposed for a new indication. ${ }^{3}$ However, the saga of hydroxychloroquine, which was touted as a cure early in the pandemic but has since proven ineffective, is a cautionary tale. ${ }^{17}$ The allure of rapid drug repurposing must be balanced against rigorous scientific method.

$\alpha_{1}$-blockers, commonly used to treat benign prostatic hyperplasia and hypertension, have become a target for drug repurposing due to pre-clinical data linking $\alpha_{1}$-adrenergic signaling to pro-inflammatory cytokines which may contribute to dysregulated immunity and adverse outcomes in COVID-19. 1,2,11 These pre-clinical findings have been bolstered by recent retrospective clinical analyses linking $\alpha_{1-}$ blockers with improved outcomes in hospitalized patients with both COVID-19 and non-COVID-19 respiratory infections. ${ }^{12,13}$ In a large COVID-19 cohort drawn from the US Veterans Health 
medRxiv preprint doi: https://doi.org/10.1101/2021.04.08.21255148; this version posted April 11, 2021. The copyright holder for this preprint (which was not certified by peer review) is the author/funder, who has granted medRxiv a license to display the preprint in perpetuity.

It is made available under a CC-BY-NC-ND 4.0 International license .

Administration hospital system, outpatient $\alpha_{1}$-blocker exposure was associated with a relative risk reduction of $18 \%$ for in-hospital mortality compared to matched controls. ${ }^{13}$ Interestingly, the nonselective $\alpha_{1}$-blocker doxazosin, which inhibits all three $\alpha_{1}$-adrenergic receptor subtypes $\left(\alpha_{1 \mathrm{~A}}, \alpha_{1 \mathrm{~B}}, \alpha_{1 \mathrm{D}}\right)$, was associated with a greater relative risk reduction (74\%) than the uroselective $\left(\alpha_{1 \mathrm{~A}}, \alpha_{1 \mathrm{D}}\right) \alpha_{1}$-blocker tamsulosin $(18 \%)$.

In the present study, we found that in-hospital use of $\alpha_{1}$-blockers was consistently and independently associated with reduced in-hospital mortality using both multivariable regression and propensity scorebased methods. In age-stratified analyses, we observed that this protective effect was more pronounced in relatively younger age groups. In contrast to the studies by Koenecke et al. and Rose et al., which defined $\alpha_{1}$-blocker exposure based on outpatient prescriptions only, we were able to use inpatient medication administration records to identify patients treated with $\alpha_{1}$-blockers during their COVID-19 hospitalization. These results lend additional support the hypothesis that $\alpha_{1}$-blockers may have a beneficial effect in COVID-19.

Our results also include tests of association between other common medication classes and COVID-19 outcomes, including beta blockers, angiotensin-converting enzyme (ACEi) inhibitors, angiotensin II receptor blockers (ARBs), and glucocorticoids. Results pertaining to these other medications should be taken in the context of a selected cohort designed to study $\alpha_{1}$-blocker use and COVID-19 outcomes. Exposures to these other classes were not ascertained with the same granularity as they were for the primary exposure. That said, it is interesting to note that $\alpha_{1}$-blocker and beta blocker exposure were associated with opposite COVID-19 outcomes in our cohort. There is evidence to suggest that $\beta$ adrenergic signaling can promote an anti-inflammatory M2 phenotype in macrophages, in contrast to the pro-inflammatory effect of $\alpha_{1}$-adrenergic signaling. ${ }^{11,18}$ Additional efforts to dissect the interactions between adrenergic signaling and the COVID-19 immune response are warranted. A prior diagnosis of asthma was associated with reduced in-hospital mortality in this analysis. While this observation deserves further scrutiny, it is conceivable that early exposure to inhaled glucocorticoids or $\beta$-adrenergic agonists may have contributed to this signal.

\section{Limitations}

Our study has several limitations. The cohort did not include women since most $\alpha_{1}$-blockers were prescribed to men, most likely for benign prostatic hyperplasia. Male sex is a recognized risk factor for adverse COVID-19 outcomes, possibly due to sex-specific differences in immunity. ${ }^{19}$ Thus, these results may not extrapolate to women. We did not account for different types of $\alpha_{1}$-blockers, which differentially target the three $\alpha_{1}$-adrenergic receptor subtypes. Importantly, a causal relationship cannot be definitively 
established between $\alpha_{1}$-blockers and improved COVID-19 outcomes in this retrospective study. Several confounders, such as older age and comorbidities were more common in the $\alpha_{1}$-blocker group. However, these adverse risk factors would be expected to bias the study result towards the null rather than inflate a protective association. Furthermore, our findings are consistent with prior data, and were robust to different methods of adjustment for confounding and sensitivity analysis. The ongoing randomized clinical trial of prazosin against placebo among hospitalized COVID-19 patients (NCT04365257) will include women and provide more definitive data on the therapeutic value of $\alpha_{1}$-blockers. Finally, our study is based on a single center EMR and medication via outpatient use cannot be tracked for adherence. Therefore, analyzing in-hospital medication administration is more robust. Furthermore, EMR in MSHS is the one of the largest and most comprehensive EMR systems, representing racial/ethnic diversity in New York City, and EMR implementation is from various data sources, so our findings are supported by large patient cohort and were robust from applying multiple methods of adjustment for confounding.

\section{Conclusions}

In conclusion, this retrospective study found a protective association between $\alpha_{1}$-blockers use and COVID-19 outcomes in a cohort of hospitalized men. These results augment the rationale for studying and repurposing $\alpha_{1}$-blockers as a COVID-19 therapeutic. We await the results of the ongoing randomized clinical trial. 
medRxiv preprint doi: https://doi.org/10.1101/2021.04.08.21255148; this version posted April 11, 2021. The copyright holder for this preprint (which was not certified by peer review) is the author/funder, who has granted medRxiv a license to display the preprint in perpetuity. It is made available under a CC-BY-NC-ND 4.0 International license .

Acknowledgement: The authors would like to acknowledge Sema4 IT for computational support hosted on AWS. JV is supported by grants from Microsoft Research and FastGrants. Author contributions: conceived and designed the study: WKO, LL and SL; performed data extraction from MSHS: SL, ZW, ES; performed statistical analysis: SL; contributed clinical interpretation: TJ, MFK, CB, JV, NP, EES, RP, RC, LL, WKO; wrote and edited the paper: SL, TJ, MFK, CB, JV, NP, EES, RP, RC, LL, WKO. Conflict of interest: Sema4 is a for-profit company currently majority owned by the Icahn School of Medicine at Mount Sinai (ISMMS). RC, EES, LL and WKO receive compensation from Sema4 that includes equity in the company. In addition to their roles with Sema4, RC, EES, LL and WKO remain affiliated with ISSMS as part-time employees and faculty members. WKO also has consulted for AAA, Astellas, AstraZeneca, Bayer, Conjupro, Foundry, Janssen, Merck, Sanofi and TeneoBio. The JHU filed a patent application on the use of various drugs to prevent cytokine release syndromes, on which NP, BV, $\mathrm{KWK}$, and SZ are listed as inventors. JHU will not assert patent rights from this filing for treatment related to COVID-19. NP is a founder of, consultant to and holds equity in Thrive an Exact company. NP is a founder of and holds equity in Personal Genome Diagnostics. NP is an advisor to and holds equity in Cage Pharma, ManaTbio and NeoPhore. CB is a consultant to Depuy-Synthes and Bionaut Labs. CB, MFK, BV, KWK, and NP are also inventors on technologies unrelated or indirectly related to the work described in this article. Licenses to these technologies are or will be associated with equity or royalty payments to the inventors, as well as to JHU. The terms of all these arrangements are being managed by JHU in accordance with its conflict of interest policies. Data and materials availability: The Mount Sinai Health System database is not publicly available. We utilized Python and R, and their open-source libraries to conduct our analysis tailored to MSH data. Therefore, we are unable to publicly release the code since it is useless without the dataset available. 
medRxiv preprint doi: https://doi.org/10.1101/2021.04.08.21255148; this version posted April 11, 2021. The copyright holder for this preprint (which was not certified by peer review) is the author/funder, who has granted medRxiv a license to display the preprint in perpetuity.

It is made available under a CC-BY-NC-ND 4.0 International license .

\section{References}

1. Qin C, Zhou L, Hu Z, et al. Dysregulation of Immune Response in Patients With Coronavirus 2019 (COVID-19) in Wuhan, China. Clinical Infectious Diseases. 2020;71(15):762-768. doi:10.1093/cid/ciaa248

2. Del Valle DM, Kim-Schulze S, Huang H-H, et al. An inflammatory cytokine signature predicts COVID-19 severity and survival. Nature Medicine. 2020;26(10):1636-1643. doi:10.1038/s41591020-1051-9

3. The RECOVERY Collaborative Group. Dexamethasone in Hospitalized Patients with Covid-19 Preliminary Report. New England Journal of Medicine. 2020;0(0):null. doi:10.1056/NEJMoa2021436

4. Salama C, Han J, Yau L, et al. Tocilizumab in Patients Hospitalized with Covid-19 Pneumonia. New England Journal of Medicine. 2021;384(1):20-30. doi:10.1056/NEJMoa2030340

5. Hermine O, Mariette X, Tharaux P-L, et al. Effect of Tocilizumab vs Usual Care in Adults Hospitalized With COVID-19 and Moderate or Severe Pneumonia: A Randomized Clinical Trial. JAMA Intern Med. 2021;181(1):32. doi:10.1001/jamainternmed.2020.6820

6. The REMAP-CAP Investigators, Gordon AC, Mouncey PR, et al. Interleukin-6 Receptor Antagonists in Critically Ill Patients with Covid-19 - Preliminary report. medRxiv. Published online January 7, 2021:2021.01.07.21249390. doi:10.1101/2021.01.07.21249390

7. RECOVERY Collaborative Group, Horby PW, Pessoa-Amorim G, et al. Tocilizumab in patients admitted to hospital with COVID-19 (RECOVERY): preliminary results of a randomised, controlled, open-label, platform trial. medRxiv. Published online February 11, 2021:2021.02.11.21249258. doi:10.1101/2021.02.11.21249258

8. Benjamin D. Randomized Master Protocol for Immune Modulators for Treating COVID-19. clinicaltrials.gov; 2021. Accessed February 15, 2021.

https://clinicaltrials.gov/ct2/show/NCT04593940

9. Tardif J-C, Bouabdallaoui N, L'Allier PL, et al. Efficacy of Colchicine in Non-Hospitalized Patients with COVID-19. medRxiv. Published online January 27, 2021:2021.01.26.21250494. doi:10.1101/2021.01.26.21250494

10. Kalil AC, Patterson TF, Mehta AK, et al. Baricitinib plus Remdesivir for Hospitalized Adults with Covid-19. New England Journal of Medicine. 2020;0(0):null. doi:10.1056/NEJMoa2031994

11. Staedtke V, Bai R-Y, Kim K, et al. Disruption of a self-amplifying catecholamine loop reduces cytokine release syndrome. Nature. 2018;564(7735):273-277. doi:10.1038/s41586-018-0774-y

12. Koenecke A, Powell M, Xiong R, et al. Alpha-1 adrenergic receptor antagonists to prevent hyperinflammation and death from lower respiratory tract infection. arXiv:200410117 [q-bio]. Published online September 8, 2020. Accessed February 16, 2021. http://arxiv.org/abs/2004.10117

13. Rose L, Graham L, Koenecke A, et al. The Association Between Alpha-1 Adrenergic Receptor Antagonists and In-Hospital Mortality from COVID-19. medRxiv. Published online February 11, 2021:2020.12.18.20248346. doi:10.1101/2020.12.18.20248346 
medRxiv preprint doi: https://doi.org/10.1101/2021.04.08.21255148; this version posted April 11, 2021. The copyright holder for this preprint

(which was not certified by peer review) is the author/funder, who has granted medRxiv a license to display the preprint in perpetuity.

It is made available under a CC-BY-NC-ND 4.0 International license.

14. Konig MF, Powell M, Staedtke V, et al. Preventing cytokine storm syndrome in COVID-19 using $\boldsymbol{\alpha}-1$ adrenergic receptor antagonists. $J$ Clin Invest. 2020;130(7):3345-3347. doi:10.1172/JCI139642

15. Demidenko E. Sample size determination for logistic regression revisited. Stat Med. 2007;26(18):3385-3397. doi:10.1002/sim.2771

16. VanderWeele TJ, Ding P. Sensitivity Analysis in Observational Research: Introducing the E-Value. Ann Intern Med. 2017;167(4):268-274. doi:10.7326/M16-2607

17. Singh B, Ryan H, Kredo T, Chaplin M, Fletcher T. Chloroquine or hydroxychloroquine for prevention and treatment of COVID-19. Cochrane Database of Systematic Reviews. 2021;(2). doi:10.1002/14651858.CD013587.pub2

18. Lamkin DM, Ho H-Y, Ong TH, et al. $\beta$-adrenergic-stimulated macrophages: Comprehensive localization in the M1-M2 spectrum. Brain Behav Immun. 2016;57:338-346. doi:10.1016/j.bbi.2016.07.162

19. Takahashi T, Iwasaki A. Sex differences in immune responses. Science. 2021;371(6527):347-348. doi:10.1126/science.abe7199 
medRxiv preprint doi: https://doi.org/10.1101/2021.04.08.21255148; this version posted April 11, 2021. The copyright holder for this preprint (which was not certified by peer review) is the author/funder, who has granted medRxiv a license to display the preprint in perpetuity.

\section{FIGURES}

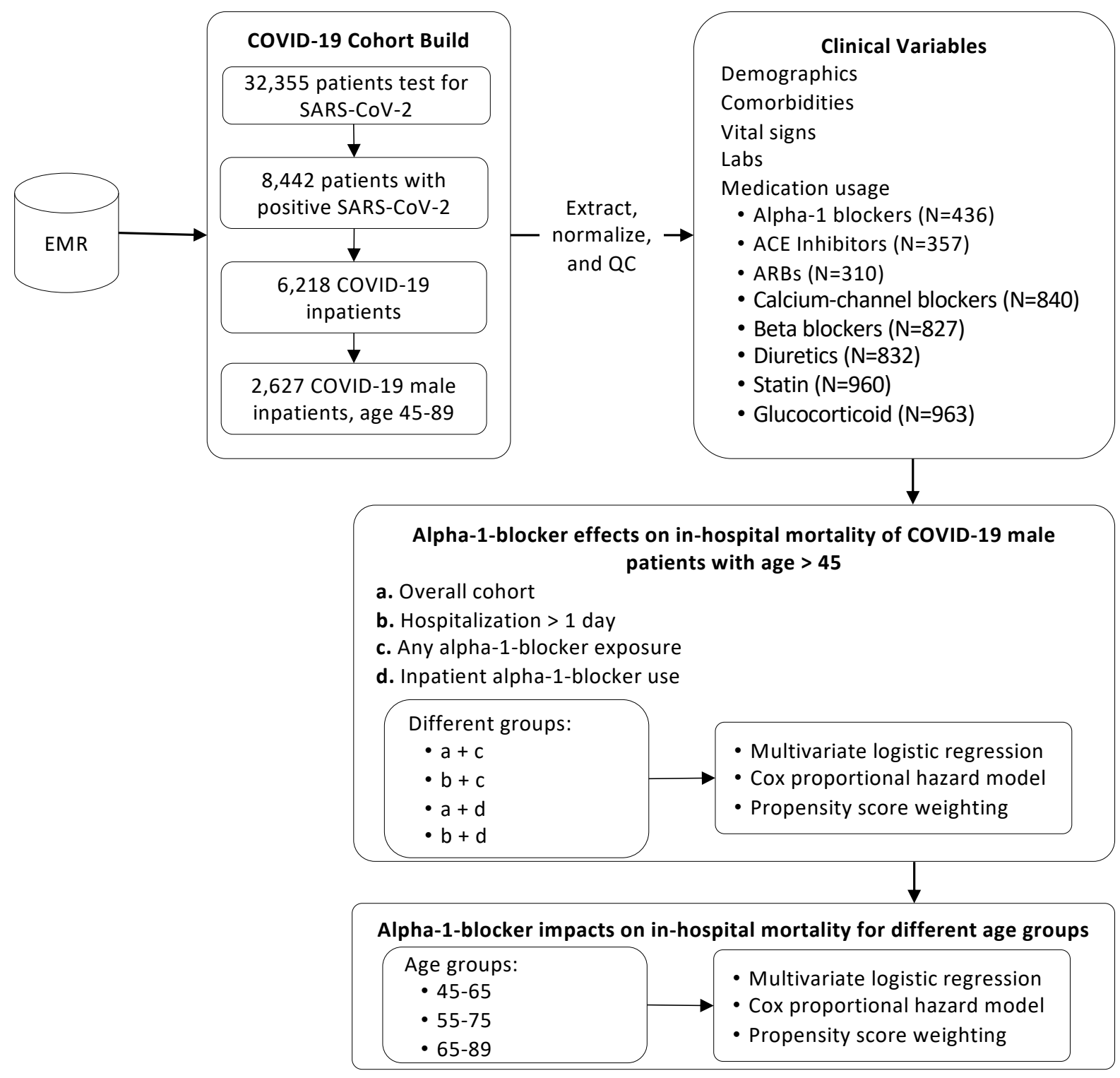

Figure 1. Schematic flowchart of data extraction and analysis plan 
medRxiv preprint doi: https://doi.org/10.1101/2021.04.08.21255148; this version posted April 11, 2021. The copyright holder for this preprint (which was not certified by peer review) is the author/funder, who has granted medRxiv a license to display the preprint in perpetuity.

It is made available under a CC-BY-NC-ND 4.0 International license .

\section{TABLES}

Table 1. Baseline characteristics and hospitalization outcomes, by alpha-1-blocker exposure

\begin{tabular}{|c|c|c|c|}
\hline $\mathbf{n}$ & $\begin{array}{l}\text { Non-Alpha-Blockers } \\
2191\end{array}$ & $\begin{array}{l}\text { Alpha-Blockers } \\
436\end{array}$ & $\begin{array}{l}\text { P- } \\
\text { Value }\end{array}$ \\
\hline \multicolumn{4}{|l|}{ Patient Characteristics } \\
\hline Age, median [Q1,Q3] & $64[56,74]$ & $73[66,81]$ & $<0.001$ \\
\hline Race, $n(\%)$ & & & 0.004 \\
\hline African-American & $514(23.5)$ & $86(19.7)$ & \\
\hline Asian & $114(5.2)$ & $19(4.4)$ & \\
\hline Hispanic & $624(28.5)$ & $130(29.8)$ & \\
\hline Other & $336(15.3)$ & $49(11.2)$ & \\
\hline Unknown & $69(3.1)$ & $10(2.3)$ & \\
\hline White & $534(24.4)$ & $142(32.6)$ & \\
\hline BMI $\left(\mathrm{kg} / \mathrm{m}^{\wedge} 2\right)$, median [Q1,Q3] & $27.0[23.8,30.9]$ & $26.0[23.2,30.0]$ & 0.003 \\
\hline Smoking status, $\mathrm{n}(\%)$ & & & $<0.001$ \\
\hline Never & $1023(46.7)$ & $202(46.3)$ & \\
\hline Not asked & $525(24.0)$ & $66(15.1)$ & \\
\hline Quit & $527(24.1)$ & $148(33.9)$ & \\
\hline Yes & $116(5.3)$ & $20(4.6)$ & \\
\hline Temperature (F), median [Q1,Q3] & $98.6[97.9,99.8]$ & $98.5[98.0,99.5]$ & 0.365 \\
\hline Max. temperature $(\mathrm{F})$, median [Q1,Q3] & $100.4[99.1,102.1]$ & $100.8[99.6,102.4]$ & $<0.001$ \\
\hline $\mathrm{O} 2$ saturation $(\%)$, median $[\mathrm{Q} 1, \mathrm{Q} 3]$ & $96.0[92.0,98.0]$ & $95.0[92.0,97.0]$ & 0.168 \\
\hline Min. O2 saturation (\%), median [Q1,Q3] & $90.0[82.0,94.0]$ & $88.0[78.0,91.0]$ & $<0.001$ \\
\hline Heart rate (BPM), median [Q1,Q3] & $94.0[82.0,108.0]$ & $91.0[77.0,104.0]$ & 0.001 \\
\hline Respiratory rate $>25, \mathrm{n}(\%)$ & $317(14.5)$ & $64(14.7)$ & 0.968 \\
\hline High BP (SBP $>140$ or DBP $>90), n(\%)$ & $817(37.3)$ & $163(37.4)$ & 0.987 \\
\hline \multicolumn{4}{|l|}{ Drugs } \\
\hline ACE inhibitors, $n(\%)$ & $267(12.2)$ & $90(20.6)$ & $<0.001$ \\
\hline ARBs, n $(\%)$ & $222(10.1)$ & $88(20.2)$ & $<0.001$ \\
\hline Diuretics, n (\%) & $629(28.7)$ & $203(46.6)$ & $<0.001$ \\
\hline Beta blockers, $\mathrm{n}(\%)$ & $623(28.4)$ & $204(46.8)$ & $<0.001$ \\
\hline Calcium-channel blockers, $\mathrm{n}(\%)$ & $627(28.6)$ & $213(48.9)$ & $<0.001$ \\
\hline Statin, n (\%) & $711(32.5)$ & $249(57.1)$ & $<0.001$ \\
\hline Glucocorticoid, n (\%) & $745(34.0)$ & $218(50.0)$ & $<0.001$ \\
\hline \multicolumn{4}{|l|}{ Comorbidities } \\
\hline Asthma, n (\%) & $52(2.4)$ & $17(3.9)$ & 0.098 \\
\hline COPD, n $(\%)$ & $76(3.5)$ & $30(6.9)$ & 0.002 \\
\hline Hypertension, n (\%) & $625(28.5)$ & $186(42.7)$ & $<0.001$ \\
\hline Obstructive Sleep Apnea, n (\%) & $36(1.6)$ & $14(3.2)$ & 0.046 \\
\hline Obesity, n (\%) & $127(5.8)$ & $29(6.7)$ & 0.563 \\
\hline Diabetes Mellitus, n (\%) & $405(18.5)$ & $130(29.8)$ & $<0.001$ \\
\hline Chronic Kidney Disease, n (\%) & $216(9.9)$ & $75(17.2)$ & $<0.001$ \\
\hline HIV, n $(\%)$ & $48(2.2)$ & $9(2.1)$ & 0.989 \\
\hline Cancer, n (\%) & $165(7.5)$ & $66(15.1)$ & $<0.001$ \\
\hline Coronary Artery Disease, n (\%) & $255(11.6)$ & $90(20.6)$ & $<0.001$ \\
\hline Atrial Fibrillation, $\mathrm{n}(\%)$ & $119(5.4)$ & $59(13.5)$ & $<0.001$ \\
\hline Heart Failure, n (\%) & $131(6.0)$ & $51(11.7)$ & $<0.001$ \\
\hline
\end{tabular}




\begin{tabular}{llll} 
Chronic Viral Hepatitis, n (\%) & $27(1.2)$ & $7(1.6)$ & 0.691 \\
Liver Disease, n (\%) & $47(2.1)$ & $13(3.0)$ & 0.372 \\
Acute Kidney Injury, n (\%) & $150(6.8)$ & $47(10.8)$ & 0.006 \\
\hline Labs & & & \\
WBC (K/uL), median [Q1,Q3] & $7.9[5.7,10.9]$ & $7.7[5.4,11.4]$ & 0.531 \\
Creatinine > 1.2, n (\%) & $903(41.2)$ & $231(53.0)$ & $<0.001$ \\
Anion Gap (mEq/L), median [Q1,Q3] & $12.3[10.7,15.0]$ & $12.4[10.2,15.0]$ & 0.413 \\
Potassium (mmol/L), median [Q1,Q3] & $4.4[4.0,4.8]$ & $4.3[3.9,4.8]$ & 0.622 \\
ALT (U/L), median [Q1,Q3] & $34.0[21.0,57.0]$ & $29.0[18.0,50.0]$ & $<0.001$ \\
\hline Hospital Conditions & & & \\
ICU, n (\%) & $431(19.7)$ & $112(25.7)$ & 0.006 \\
Days after infection, median [Q1,Q3] & $4.7[1.1,9.5]$ & $7.0[3.6,11.5]$ & $<0.001$ \\
Hospital status, n (\%) & & & $<0.001$ \\
$\quad$ Censored & $214(9.8)$ & $66(15.1)$ & \\
$\quad$ Deceased & $617(28.2)$ & $141(32.3)$ & \\
$\quad$ Discharged & $1360(62.1)$ & $229(52.5)$ & \\
\hline
\end{tabular}

Abbreviations: BMI, body mass index; BPM, beats per minute; BP, blood pressure; SBP, systolic blood pressure; DBP, diastolic blood pressure; ACE, angiotensin-converting enzyme; ARBs, angiotensin II receptor blockers; COPD, chronic obstructive pulmonary disease; HIV, human immunodeficient virus; WBC, white blood cell count; ALT, alanine aminotransferase 
Table 2. Multivariable logistic regression results for COVID-19 in-hospital mortality, by cohort (overall vs. hospitalization >1 day) and alpha-1blocker exposure (any vs. inpatient use)

\begin{tabular}{|c|c|c|c|c|c|c|c|c|}
\hline & \multicolumn{2}{|c|}{$\begin{array}{l}\text { Overall cohort, any exposure } \\
(\mathrm{N}=2347)\end{array}$} & \multicolumn{2}{|c|}{$\begin{array}{c}\text { Overall cohort, inpatient use } \\
(\mathrm{N}=2276)\end{array}$} & \multicolumn{2}{|c|}{$\begin{array}{c}\text { Hospital stay }>1 \text { day, any } \\
\text { exposure }(\mathrm{N}=1789)\end{array}$} & \multicolumn{2}{|c|}{$\begin{array}{l}\text { Hospital stay > } 1 \text { day, } \\
\text { inpatient use }(\mathrm{N}=1744)\end{array}$} \\
\hline & $\begin{array}{l}\text { Adjusted OR (95\% } \\
\text { CI) }\end{array}$ & $\begin{array}{l}\text { p- } \\
\text { value }\end{array}$ & $\begin{array}{l}\text { Adjusted OR (95\% } \\
\text { CI) }\end{array}$ & $\begin{array}{l}\text { p- } \\
\text { value }\end{array}$ & $\begin{array}{l}\text { Adjusted OR } \\
(95 \% \mathrm{CI})\end{array}$ & $\begin{array}{l}\text { p- } \\
\text { value }\end{array}$ & $\begin{array}{l}\text { Adjusted OR } \\
(95 \% \text { CI })\end{array}$ & $\begin{array}{l}\text { p- } \\
\text { value }\end{array}$ \\
\hline \multicolumn{9}{|l|}{ Drugs } \\
\hline Alpha-1 blockers & $0.749(0.527-1.064)$ & 0.106 & $0.633(0.434-0.921)$ & 0.017 & $0.722(0.505-1.034)$ & 0.075 & $0.607(0.415-0.890)$ & 0.010 \\
\hline ACE inhibitors & $1.331(0.880-2.014)$ & 0.175 & $1.237(0.808-1.893)$ & 0.327 & $1.317(0.861-2.016)$ & 0.205 & $1.220(0.787-1.891)$ & 0.373 \\
\hline ARBs & $05(0.660-1.528)$ & 0.983 & $1.030(0.667-1.592)$ & 0.893 & $0.872(0.562-1.353)$ & 0.541 & $0.900(0.572-1.419)$ & 0.652 \\
\hline Diuretics & $1.595(1.147-2.217)$ & 0.006 & $1.571(1.123-2.199)$ & 0.008 & $1.520(1.084-2.132)$ & 0.015 & $1.464(1.037-2.067)$ & 0.030 \\
\hline Beta blockers & $1.448(1.067-1.966)$ & 0.017 & $1.534(1.123-2.094)$ & 0.007 & $1.505(1.103-2.054)$ & 0.010 & $1.578(1.148-2.168)$ & 0.005 \\
\hline $\begin{array}{l}\text { Calcium-channel } \\
\text { blockers }\end{array}$ & $0.736(0.535-1.012)$ & 0.059 & $0.698(0.503-0.968)$ & 0.031 & $0.758(0.547-1.050)$ & 0.095 & $0.710(0.508-0.991)$ & 0.044 \\
\hline Statin & $524-1.200)$ & 0.386 & $03(0.647-1.261)$ & 550 & $0.925(0.661-1.293)$ & 0.646 & $0.967(0.686-1.361)$ & 0.844 \\
\hline Glucocorticoid & 04) & 0.064 & 1.422 & 0.041 & $1.467(1.044-$ & 0.027 & $1.495(1.058-2.115)$ & 0.023 \\
\hline \multicolumn{9}{|l|}{ Patient Characteristics } \\
\hline Age & $1.095)$ & $<0.001$ & $64-1.099)$ & $<0.001$ & $1.084(1.067-1.102)$ & $<0.001$ & $-1.103)$ & $<0.001$ \\
\hline Race: & $463-1.063)$ & 0.095 & 473-1.102) & 0.131 & $0.826(0.539-1.266)$ & 0.381 & 0.838 & 0.424 \\
\hline Race: Asian & $0.637(0.311-1.307)$ & 0.219 & $0.554(0.260-1.179)$ & 0.126 & $0.708(0.342-1.468)$ & 0.354 & $0.600(0.279-1.294)$ & 0.193 \\
\hline Race: Hispanic & $0.776(0.525-1.147)$ & 0.202 & $0.786(0.526-1.174)$ & 0.238 & $0.872(0.582-1.306)$ & 0.507 & $0.872(0.577-1.319)$ & 0.516 \\
\hline Race: Other & $0.650(0.405-1.043)$ & 0.074 & $0.673(0.417-1.087)$ & 0.105 & $0.763(0.470-1.237)$ & 0.273 & $0.780(0.479-1.273)$ & 0.321 \\
\hline Race: Unknown & $25(0.293-1.795)$ & 0.488 & $0.737(0.296-1.839)$ & 0.513 & $0.818(0.329-2.030)$ & 0.664 & $0.825(0.330-2.065)$ & 0.682 \\
\hline $\begin{array}{l}\text { Smoking Status: Not } \\
\text { Asked }\end{array}$ & 678-1.477) & 0.996 & 6) & 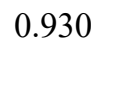 & $0.932(0.626-1.388)$ & 0.731 & $0.941(0.629-1.406)$ & 0.765 \\
\hline Smoking Status: Quit & $51(0.949-1.923)$ & 0.095 & $1.302(0.906-1.872)$ & .154 & $1.306(0.909-1.876)$ & 0.148 & $1.309(0.902-1.896)$ & 0.156 \\
\hline Smoking Status: Yes & $-2.545)$ & 0.494 & $676-2.710)$ & 0.393 & $1.232(0.604-2.514)$ & 0.566 & $1.335(0.652-2.732)$ & 0.430 \\
\hline BMI & $1.011(0.989-1.035)$ & 0.326 & $1.013(0.991-1.037)$ & 0.251 & $1.013(0.990-1.038)$ & 0.271 & $1.014(0.991-1.039)$ & 0.233 \\
\hline Temperature & $0.991(0.930-1.057)$ & 0.779 & $0.993(0.931-1.061)$ & 0.842 & $0.991(0.928-1.059)$ & 0.781 & $0.992(0.928-1.061)$ & 0.820 \\
\hline Max. Temperature & $1.221(1.122-1.331)$ & $<0.001$ & $1.212(1.112-1.322)$ & $<0.001$ & $1.262(1.154-1.380)$ & $<0.001$ & $1.247(1.139-1.366)$ & $<0.001$ \\
\hline O2 Saturation & $13(0.991-1.037)$ & 0.243 & $1.014(0.992-1.037)$ & 0.220 & $1.006(0.983-1.029)$ & 0.617 & $1.008(0.984-1.031)$ & 0.513 \\
\hline Min. O2 Saturation & $0.932(0.919-0.946)$ & $<0.001$ & $0.932(0.919-0.946)$ & $<0.001$ & $0.934(0.920-0.947)$ & $<0.001$ & $0.933(0.919-0.946)$ & $<0.001$ \\
\hline Heart Rate & $0.996(0.989-1.004)$ & 0.353 & $0.995(0.987-1.003)$ & 0.201 & $0.995(0.987-1.003)$ & 0.219 & $0.994(0.986-1.002)$ & 0.164 \\
\hline Respiratory Rate $>25$ & $1.699(1.151-2.504)$ & 0.007 & $1.649(1.107-2.452)$ & 0.014 & $1.511(1.010-2.261)$ & 0.045 & $1.476(0.977-2.228)$ & 0.064 \\
\hline $\begin{array}{l}\text { High BP (SBP }>140 \text { or } \\
\text { DBP }>90)\end{array}$ & $1.161(0.863-1.560)$ & 0.324 & $1.169(0.863-1.584)$ & 0.312 & $1.219(0.900-1.650)$ & 0.200 & $1.234(0.905-1.682)$ & 0.184 \\
\hline $\begin{array}{l}\text { Comorbidities } \\
\text { Asthma }\end{array}$ & $0.259(0.088-0.765)$ & 0.015 & $0.299(0.099-0.900)$ & 0.032 & $0.280(0.095-0.823)$ & 0.021 & $0.323(0.109-0.962)$ & 0.042 \\
\hline
\end{tabular}




\begin{tabular}{|c|c|c|c|c|c|c|c|c|}
\hline COPD & $1.505(0.771-2.939)$ & 0.231 & $1.342(0.672-2.678)$ & 0.405 & $1.498(0.752-2.980)$ & 0.250 & $1.296(0.633-2.651)$ & 0.479 \\
\hline Hypertension & $0.825(0.570-1.196)$ & 0.311 & $0.851(0.580-1.249)$ & 0.409 & $0.817(0.558-1.196)$ & 0.299 & $0.837(0.564-1.241)$ & 0.376 \\
\hline Obstructive Sleep Apnea & $3.025(1.175-7.791)$ & 0.022 & $3.019(1.163-7.838)$ & 0.023 & $3.074(1.164-8.125)$ & 0.023 & $3.152(1.179-8.415)$ & 0.022 \\
\hline Obesity & $1.048(0.568-1.935)$ & 0.880 & $1.064(0.567-1.998)$ & 0.847 & $0.919(0.485-1.742)$ & 0.797 & $0.924(0.479-1.784)$ & 0.815 \\
\hline Diabetes Mellitus & $1.043(0.710-1.533)$ & 0.829 & $0.986(0.664-1.465)$ & 0.946 & $1.099(0.737-1.639)$ & 0.643 & $1.025(0.679-1.547)$ & 0.907 \\
\hline Chronic Kidney Disease & $1.188(0.737-1.914)$ & 0.479 & $1.264(0.774-2.063)$ & 0.349 & $1.322(0.810-2.158)$ & 0.264 & $1.412(0.854-2.333)$ & 0.179 \\
\hline HIV & $1.846(0.688-4.948)$ & 0.224 & $1.696(0.600-4.792)$ & 0.319 & $1.702(0.604-4.802)$ & 0.314 & $1.480(0.494-4.433)$ & 0.484 \\
\hline Cancer & $0.959(0.601-1.530)$ & 0.861 & $0.862(0.530-1.398)$ & 0.546 & $0.882(0.546-1.426)$ & 0.609 & $0.831(0.506-1.365)$ & 0.464 \\
\hline Coronary Artery Disease & $0.807(0.514-1.265)$ & 0.350 & $0.783(0.492-1.249)$ & 0.305 & $0.880(0.550-1.406)$ & 0.593 & $0.899(0.555-1.455)$ & 0.663 \\
\hline Atrial Fibrillation & $0.779(0.457-1.330)$ & 0.360 & $0.740(0.428-1.279)$ & 0.281 & $0.768(0.444-1.328)$ & 0.345 & $0.726(0.414-1.275)$ & 0.266 \\
\hline Heart Failure & $1.004(0.576-1.749)$ & 0.989 & $1.041(0.587-1.846)$ & 0.891 & $0.838(0.466-1.507)$ & 0.554 & $0.836(0.454-1.540)$ & 0.566 \\
\hline Chronic Viral Hepatitis & $0.546(0.146-2.040)$ & 0.368 & $0.596(0.158-2.255)$ & 0.446 & $0.580(0.155-2.179)$ & 0.420 & $0.630(0.166-2.394)$ & 0.497 \\
\hline Liver Disease & $1.448(0.593-3.536)$ & 0.417 & $1.486(0.607-3.636)$ & 0.386 & $1.573(0.639-3.873)$ & 0.325 & $1.613(0.654-3.983)$ & 0.299 \\
\hline Acute Kidney Injury & $1.157(0.689-1.944)$ & 0.581 & $1.009(0.582-1.747)$ & 0.975 & $1.204(0.708-2.048)$ & 0.493 & $1.107(0.635-1.933)$ & 0.718 \\
\hline \multicolumn{9}{|l|}{ Labs } \\
\hline WBC & $1.028(1.000-1.058)$ & 0.052 & $1.029(1.001-1.060)$ & 0.043 & $1.019(0.988-1.052)$ & 0.234 & $1.020(0.988-1.053)$ & 0.212 \\
\hline Creatinine $>1.2$ & $1.660(1.184-2.330)$ & 0.003 & $1.598(1.130-2.261)$ & 0.008 & $1.462(1.035-2.067)$ & 0.031 & $1.438(1.009-2.048)$ & 0.045 \\
\hline Anion Gap & $1.074(1.035-1.114)$ & $<0.001$ & $1.075(1.036-1.116)$ & $<0.001$ & $1.063(1.024-1.103)$ & 0.001 & $1.063(1.023-1.104)$ & 0.001 \\
\hline Potassium & $1.223(1.016-1.471)$ & 0.033 & $1.191(0.985-1.441)$ & 0.072 & $1.219(1.010-1.473)$ & 0.039 & $1.184(0.975-1.438)$ & 0.088 \\
\hline ALT & $1.001(0.999-1.003)$ & 0.309 & $1.001(0.999-1.004)$ & 0.271 & $1.001(0.999-1.003)$ & 0.349 & $1.001(0.999-1.003)$ & 0.364 \\
\hline \multicolumn{9}{|l|}{ Hospital Conditions } \\
\hline ICU & $3.547(2.433-5.165)$ & $<0.001$ & $3.740(2.550-5.479)$ & $<0.001$ & $3.219(2.197-4.711)$ & $<0.001$ & $3.425(2.323-5.048)$ & $<0.001$ \\
\hline Duration (days) & $0.956(0.933-0.979)$ & $<0.001$ & $0.958(0.934-0.981)$ & $<0.001$ & $0.959(0.936-0.983)$ & 0.001 & $0.962(0.939-0.986)$ & 0.002 \\
\hline
\end{tabular}

Abbreviations: ACE, angiotensin-converting enzyme; ARBs, angiotensin II receptor blockers; BMI, body mass index; BP, blood pressure; SBP, systolic blood pressure; DBP, diastolic blood pressure; COPD, chronic obstructive pulmonary disease; HIV, human immunodeficient virus; WBC, white blood cell count; ALT, alanine aminotransferase 
Table 3. Multivariable Cox regression results for COVID-19 in-hospital mortality, by cohort (overall vs. hospitalization $>1$ day) and alpha-1blocker exposure (any vs. inpatient use)

\begin{tabular}{|c|c|c|c|c|c|c|c|c|}
\hline & \multicolumn{2}{|c|}{$\begin{array}{c}\text { Overall cohort, any exposure } \\
(\mathrm{N}=\mathbf{2 6 2 7 )}\end{array}$} & \multicolumn{2}{|c|}{$\begin{array}{l}\text { Overall cohort, inpatient use } \\
(\mathrm{N}=2534)\end{array}$} & \multicolumn{2}{|c|}{$\begin{array}{c}\text { Hospital stay }>1 \text { day, any } \\
\text { exposure }(N=2037)\end{array}$} & \multicolumn{2}{|c|}{$\begin{array}{l}\text { Hospital stay > } 1 \text { day, } \\
\text { inpatient use }(\mathrm{N}=1973)\end{array}$} \\
\hline & $\operatorname{HR}(95 \% \mathrm{CI})$ & $\begin{array}{c}\mathrm{P}- \\
\text { value }\end{array}$ & HR (95\% CI) & $\begin{array}{c}\mathrm{P}- \\
\text { value }\end{array}$ & HR (95\% CI) & $\begin{array}{c}\mathrm{P}- \\
\text { value }\end{array}$ & HR (95\% CI) & $\begin{array}{c}\mathrm{P}- \\
\text { value }\end{array}$ \\
\hline \multicolumn{9}{|l|}{ Drugs } \\
\hline Alpha-1 blockers & $808(0.652-1.002)$ & 0.052 & $0.721(0.572-0.908)$ & 0.006 & $0.823(0.660-1.027)$ & 0.085 & $0.751(0.593-0.950)$ & 0.017 \\
\hline ACE inhibitors & $166(0.910-1.494)$ & 0.224 & $1.149(0.887-1.487)$ & 0.292 & $1.151(0.892-1.486)$ & 0.280 & $1.121(0.859-1.462)$ & 0.402 \\
\hline $\mathrm{ARBs}$ & $1.330(1.035-1.709)$ & 0.026 & $1.319(1.018-1.710)$ & 0.036 & $1.152(0.880-1.509)$ & 0.302 & $1.145(0.867-1.512)$ & 0.341 \\
\hline Diuretics & $0.895(0.729-1.098)$ & 0.286 & $0.863(0.700-1.065)$ & 0.169 & $0.859(0.694-1.064)$ & 0.164 & $0.825(0.663-1.026)$ & 0.084 \\
\hline Beta blockers & $1.073(0.895-1.287)$ & 0.446 & $1.090(0.905-1.313)$ & 0.363 & $1.100(0.912-1.327)$ & 0.317 & $1.120(0.925-1.356)$ & 0.247 \\
\hline $\begin{array}{l}\text { Calcium-channel } \\
\text { blockers }\end{array}$ & $0.637(0.530-0.766)$ & $<0.001$ & $0.613(0.508-0.740)$ & $<0.001$ & $0.649(0.537-0.785)$ & $<0.001$ & $0.629(0.518-0.764)$ & $<0.001$ \\
\hline Statin & $0.970(0.800-1.175)$ & 0.753 & $0.951(0.778-1.162)$ & 0.621 & $1.007(0.825-1.228)$ & 0.949 & $0.999(0.812-1.228)$ & 0.990 \\
\hline Glucocorticoid & $0.767(0.627-0.938)$ & 0.010 & $0.789(0.642-0.971)$ & 0.025 & $0.801(0.649-0.988)$ & 0.038 & $0.820(0.661-1.016)$ & 0.070 \\
\hline \multicolumn{9}{|l|}{ Patient Characteristics } \\
\hline Age & $1.035(1.025-1.044)$ & - & $.033(1.024-1.043)$ & 0.001 & $1.037(1.0$ & $<0.001$ & $025(10$ & 0.001 \\
\hline Race: African American & $0.813(0.633-1.043)$ & 0.104 & $0.824(0.639-1.064)$ & 0.137 & $0.906(0.699-1.175)$ & 0.457 & $0.909(0.698-1.184)$ & 0.480 \\
\hline Race: Asian & $0.829(0.536-1.284)$ & 0.401 & $0.773(0.488-1.224)$ & 0.272 & $0.841(0.533-1.326)$ & 0.456 & $0.760(0.470-1.230)$ & 0.264 \\
\hline Race: $\mathrm{H}$ & $0.881(0.698-1.112)$ & 0.286 & $0.866(0.682-1.099)$ & 0.237 & $0.928(0.727-1.184)$ & 0.548 & $0.919(0.716-1.178)$ & 0.504 \\
\hline Race: Other & $0.972(0.738-1.279)$ & 0.839 & $0.972(0.737-1.284)$ & 0.843 & $1.043(0.784-1.389)$ & 0.773 & $1.035(0.775-1.382)$ & 0.816 \\
\hline Race: Unknown & $0.961(0.578-1.599)$ & 0.879 & $0.982(0.589-1.636)$ & 0.944 & $1.043(0.625-1.741)$ & 0.871 & $1.060(0.634-1.772)$ & 0.824 \\
\hline $\begin{array}{l}\text { Smoking Status: Not } \\
\text { Asked }\end{array}$ & $1.089(0.865-1.371)$ & 0.467 & $1.084(0.858-1.369)$ & 0.499 & $1.065(0.840-1.351)$ & 0.603 & $1.085(0.853-1.379)$ & 0.507 \\
\hline Smoking Status: Quit & 58) & 0 & 7) & 0.028 & 1.25 & 0.044 & 1.293 & 0.025 \\
\hline Smoking Status: Yes & $1.090(0.714-1.664)$ & 0.690 & $4(0.719-1.695)$ & 0.652 & $1.065(0.689-1.645)$ & 0.778 & $1.094(0.704-1.702)$ & 0.689 \\
\hline BMI & $1.008(0.996-1.020)$ & 0.168 & $1.008(0.996-1.021)$ & 0.172 & $1.009(0.997-1.022)$ & 0.134 & $1.009(0.997-1.021)$ & 0.153 \\
\hline Temp & $1.021(0.972-1.072)$ & 0.406 & $1.013(0.966-1.062)$ & 0.595 & $1.012(0.964-1.062)$ & 0.621 & $1.006(0.960-1.055)$ & 0.789 \\
\hline Max. Temperature & $1.016(0.963-1.071)$ & 0.562 & $1.013(0.959-1.069)$ & 0.646 & $1.061(1.007-1.117)$ & 0.025 & $1.058(1.004-1.115)$ & 0.035 \\
\hline O2 Saturation & $0.990(0.979-1.000)$ & 0.057 & $80-1.002)$ & 0.112 & $0.988(0.977-0.999)$ & 0.036 & $0.989(0.978-1.001)$ & 0.069 \\
\hline Min. O2 Saturation & $0.991(0.988-0.995)$ & $<0.001$ & $0.991(0.988-0.995)$ & $<0.001$ & $0.993(0.989-0.997)$ & 0.001 & $0.993(0.989-0.997)$ & $<0.001$ \\
\hline Heart Rate & $1.000(0.995-1.004)$ & 0.939 & $0.999(0.994-1.003)$ & 0.605 & $1.000(0.995-1.005)$ & 0.920 & $0.999(0.994-1.004)$ & 0.779 \\
\hline Respiratory Rate $>25$ & $1.155(0.939-1.420)$ & 0.173 & $1.136(0.918-1.405)$ & 0.241 & $1.109(0.893-1.378)$ & 0.349 & $1.101(0.882-1.374)$ & 0.395 \\
\hline $\begin{array}{l}\text { High BP (SBP }>140 \text { or } \\
\text { DBP }>90)\end{array}$ & $1.070(0.898-1.275)$ & 0.451 & $1.095(0.915-1.310)$ & 0.323 & $1.135(0.946-1.361)$ & 0.172 & $1.156(0.960-1.392)$ & 0.125 \\
\hline $\begin{array}{l}\text { Comorbidities } \\
\text { Asthma }\end{array}$ & $0.501(0.234-1.072)$ & 0.075 & $0.534(0.249-1.147)$ & 0.108 & $0.536(0.250-1.149)$ & 0.109 & $0.582(0.271-1.250)$ & 0.165 \\
\hline
\end{tabular}




\begin{tabular}{|c|c|c|c|c|c|c|c|c|}
\hline COPD & $1.254(0.871-1.805)$ & 0.224 & $1.121(0.758-1.657)$ & 0.568 & $1.280(0.876-1.872)$ & 0.202 & $1.130(0.752-1.699)$ & 0.557 \\
\hline Hypertension & $0.877(0.696-1.103)$ & 0.261 & $0.881(0.695-1.118)$ & 0.298 & $0.857(0.676-1.088)$ & 0.205 & $0.850(0.665-1.086)$ & 0.193 \\
\hline Obstructive Sleep Apnea & $1.257(0.721-2.193)$ & 0.420 & $1.405(0.794-2.486)$ & 0.242 & $1.138(0.631-2.054)$ & 0.667 & $1.267(0.690-2.329)$ & 0.445 \\
\hline Obesity & $0.954(0.667-1.363)$ & 0.795 & $0.998(0.695-1.434)$ & 0.992 & $0.954(0.658-1.382)$ & 0.802 & $0.999(0.685-1.456)$ & 0.996 \\
\hline Diabetes Mellitus & $0.986(0.785-1.239)$ & 0.904 & $0.981(0.776-1.240)$ & 0.873 & $0.970(0.765-1.229)$ & 0.798 & $0.954(0.748-1.216)$ & 0.703 \\
\hline Chronic Kidney Disease & $0.920(0.694-1.220)$ & 0.564 & $0.958(0.718-1.278)$ & 0.769 & $1.050(0.784-1.405)$ & 0.743 & $1.090(0.809-1.468)$ & 0.572 \\
\hline HIV & $0.943(0.515-1.728)$ & 0.850 & $0.878(0.467-1.653)$ & 0.688 & $0.901(0.478-1.698)$ & 0.748 & $0.848(0.437-1.644)$ & 0.625 \\
\hline Cancer & $1.255(0.947-1.663)$ & 0.114 & $1.213(0.903-1.627)$ & 0.199 & $1.237(0.922-1.660)$ & 0.156 & $1.200(0.884-1.630)$ & 0.243 \\
\hline Coronary Artery Disease & $1.190(0.917-1.544)$ & 0.192 & $1.231(0.940-1.613)$ & 0.131 & $1.236(0.941-1.625)$ & 0.128 & $1.298(0.978-1.721)$ & 0.071 \\
\hline Atrial Fibrillation & $1.306(0.944-1.807)$ & 0.107 & $1.353(0.966-1.893)$ & 0.078 & $1.278(0.905-1.806)$ & 0.163 & $1.295(0.904-1.854)$ & 0.158 \\
\hline Heart Failure & $1.499(1.092-2.058)$ & 0.012 & $1.538(1.108-2.135)$ & 0.010 & $1.314(0.932-1.852)$ & 0.119 & $1.299(0.908-1.859)$ & 0.153 \\
\hline Chronic Viral Hepatitis & $1.193(0.482-2.954)$ & 0.703 & $1.336(0.537-3.321)$ & 0.534 & $1.326(0.533-3.300)$ & 0.544 & $1.501(0.600-3.755)$ & 0.386 \\
\hline Liver Disease & $1.191(0.708-2.004)$ & 0.509 & $1.184(0.698-2.009)$ & 0.531 & $1.276(0.750-2.170)$ & 0.369 & $1.268(0.739-2.173)$ & 0.389 \\
\hline Acute Kidney Injury & $0.878(0.656-1.175)$ & 0.381 & $0.823(0.603-1.123)$ & 0.219 & $0.935(0.690-1.266)$ & 0.664 & $0.887(0.643-1.223)$ & 0.464 \\
\hline \multicolumn{9}{|l|}{ Labs } \\
\hline WBC & $1.012(0.995-1.028)$ & 0.162 & $1.018(1.000-1.036)$ & 0.047 & $1.005(0.987-1.023)$ & 0.605 & $1.010(0.991-1.029)$ & 0.315 \\
\hline Creatinine $>1.2$ & $1.353(1.108-1.654)$ & 0.003 & $1.337(1.089-1.641)$ & 0.006 & $1.281(1.042-1.575)$ & 0.019 & $1.288(1.043-1.591)$ & 0.019 \\
\hline Anion Gap & $1.042(1.022-1.062)$ & $<0.001$ & $1.040(1.019-1.061)$ & $<0.001$ & $1.032(1.010-1.054)$ & 0.004 & $1.028(1.005-1.051)$ & 0.015 \\
\hline Potassium & $1.125(1.019-1.241)$ & 0.019 & $1.103(0.996-1.221)$ & 0.060 & $1.103(0.994-1.225)$ & 0.064 & $1.081(0.971-1.204)$ & 0.154 \\
\hline ALT & $1.000(0.999-1.001)$ & 0.727 & $1.000(0.999-1.001)$ & 0.757 & $1.000(0.999-1.001)$ & 0.688 & $1.000(0.999-1.001)$ & 0.758 \\
\hline \multicolumn{9}{|l|}{ Hospital Conditions } \\
\hline $\mathrm{ICU}$ & $1.350(1.094-1.667)$ & 0.005 & $1.425(1.149-1.768)$ & 0.001 & $1.382(1.109-1.723)$ & 0.004 & $1.437(1.148-1.800)$ & 0.002 \\
\hline
\end{tabular}

Abbreviations: ACE, angiotensin-converting enzyme; ARBs, angiotensin II receptor blockers; BMI, body mass index; BP, blood pressure; SBP, systolic blood pressure; DBP, diastolic blood pressure; COPD, chronic obstructive pulmonary disease; HIV, human immunodeficient virus; WBC, white blood cell count; ALT, alanine aminotransferase 
Table 4. Age-stratified multivariable logistic regression and propensity-weighted logistic regression analyses for COVID-19 in-hospital mortality, by cohort (overall vs. hospitalization $>1$ day) and alpha-1-blocker exposure (any vs. inpatient use)

\begin{tabular}{|c|c|c|c|c|c|c|}
\hline & \multicolumn{2}{|c|}{ Age 45-65 (N=1159) } & \multicolumn{2}{|c|}{ Age 55-75(N=1312) } & \multicolumn{2}{|c|}{ Age 65-89 $(\mathrm{N}=1176)$} \\
\hline & $\begin{array}{c}\text { Adjusted OR (95\% } \\
\text { CI) }\end{array}$ & $\begin{array}{c}\mathrm{p}- \\
\text { value }\end{array}$ & $\begin{array}{c}\text { Adjusted OR (95\% } \\
\text { CI) }\end{array}$ & $\begin{array}{c}\text { p- } \\
\text { value }\end{array}$ & $\begin{array}{c}\text { Adjusted OR (95\% } \\
\text { CI) }\end{array}$ & $\begin{array}{c}\text { p- } \\
\text { value }\end{array}$ \\
\hline Overall cohort, any exposure & $0.511(0.232-1.126)$ & 0.096 & $0.603(0.362-1.003)$ & 0.051 & $0.908(0.588-1.402)$ & 0.663 \\
\hline Overall cohort, inpatient use & $0.384(0.164-0.896)$ & 0.027 & $0.511(0.297-0.880)$ & 0.015 & $0.810(0.509-1.289)$ & 0.374 \\
\hline \multicolumn{7}{|c|}{ Inverse propensity-weighted logistic regression } \\
\hline Overall cohort, any exposure & $0.298(0.132-0.672)$ & 0.004 & $0.552(0.337-0.903)$ & 0.018 & $0.876(0.557-1.379)$ & 0.568 \\
\hline Overall cohort, inpatient use & $0.268(0.109-0.658)$ & 0.004 & $0.424(0.247-0.725)$ & 0.002 & $0.801(0.487-1.317)$ & 0.382 \\
\hline Hospital stay $>1$ day, any exposure & $0.314(0.141-0.698)$ & 0.005 & $0.535(0.321-0.89)$ & 0.016 & $0.800(0.500-1.280)$ & 0.353 \\
\hline
\end{tabular}


medRxiv preprint doi: https://doi.org/10.1101/2021.04.08.21255148; this version posted April 11, 2021. The copyright holder for this preprint (which was not certified by peer review) is the author/funder, who has granted medRxiv a license to display the preprint in perpetuity.

It is made available under a CC-BY-NC-ND 4.0 International license .

\section{SUPPLEMENTARY MATERIALS}

Figure S1. Age distributions of $\alpha_{1}$-blockers exposed and unexposed groups

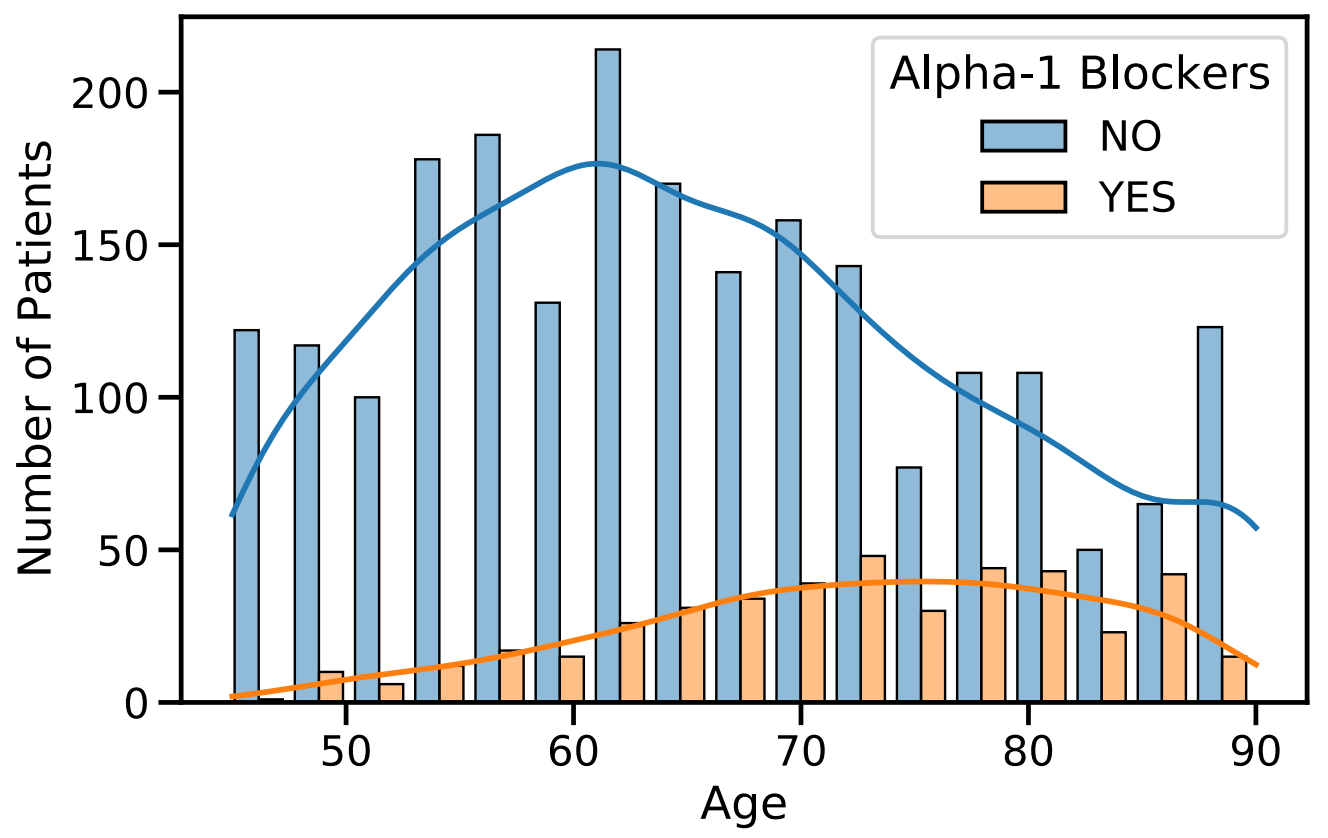


medRxiv preprint doi: https://doi.org/10.1101/2021.04.08.21255148; this version posted April 11, 2021. The copyright holder for this preprint

(which was not certified by peer review) is the author/funder, who has granted medRxiv a license to display the preprint in perpetuity.

It is made available under a CC-BY-NC-ND 4.0 International license .

Table S1a. Medication categories and individual medications

\begin{tabular}{c|l}
\hline Medication Category & \multicolumn{1}{c}{ Medication Names } \\
\hline Alpha-1 Blockers & Tamsulosin, Alfuzosin, Silodosin, Terazosin, Doxazosin, Prazosin \\
\hline ACE inhibitors & $\begin{array}{l}\text { Benazepril hydrochloride, Captopril, Enalapril maleate, Fosinopril sodium, } \\
\text { Lisinopril, Moexipril, Perindopril, Quinapril hydrochloride, Ramipril, } \\
\text { Trandolapril }\end{array}$ \\
\hline ARBs & $\begin{array}{l}\text { Azilsartan, Candesartan, Eprosartan mesylate, Irbesartan, losartan } \\
\text { potassium, Olmesartan, Telmisartan, Valsartan }\end{array}$ \\
\hline Diuretics & $\begin{array}{l}\text { Chlorthalidone, Chlorothiazide, Hydrochlorothiazide, Indapamide, } \\
\text { Metolazone, Amiloride hydrochloride, Spironolactone, Triamterene, } \\
\text { Eplerenone, Furosemide, Bumetanide, Torsemide, Ethacrynic acid }\end{array}$ \\
\hline Beta Blockers & $\begin{array}{l}\text { Acebutolol, Atenolol, Betaxolol, Bisoprolol fumarate, Carteolol } \\
\text { hydrochloride, Metoprolol, Nadolol, Nebivolol, Penbutolol sulfate, Pindolol, } \\
\text { Propranolol hydrochloride, Solotol hydrochloride, Timolol maleate }\end{array}$ \\
\hline Calcium-channel & $\begin{array}{l}\text { Amlodipine, Bepridil, Diltiazem hydrochloride, Felodipine, Isradipine, } \\
\text { Nicardipine, Nifedipine, Nisoldipine, Verapamil hydrochloride }\end{array}$ \\
Blockers & $\begin{array}{l}\text { Atorvastatin, Fluvastatin, Lovastatin, Pitavastatin, Pravastatin, Rosuvastatin, } \\
\text { Simvastatin }\end{array}$ \\
\hline Statin & $\begin{array}{l}\text { Methylprednisolone, Prednisone, Hydrocortisone, Dexamethasone, } \\
\text { Fludrocortisone, Triamcinolone, Prednisolone, Betamethasone }\end{array}$ \\
\hline Glucocorticoid
\end{tabular}

Table SIb. Number of patients exposed to glucocorticoid medications

\begin{tabular}{ll}
\hline Drug Name & Number of Patients \\
\hline Methylprednisolone & 621 \\
Prednisone & 269 \\
Hydrocortisone & 242 \\
Dexamethasone & 189 \\
Fludrocortisone & 41 \\
Triamcinolone & 29 \\
Prednisolone & 23 \\
Betamethasone & 10 \\
\hline
\end{tabular}


medRxiv preprint doi: https://doi.org/10.1101/2021.04.08.21255148; this version posted April 11, 2021. The copyright holder for this preprint (which was not certified by peer review) is the author/funder, who has granted medRxiv a license to display the preprint in perpetuity.

It is made available under a CC-BY-NC-ND 4.0 International license .

Table S2. Sensitivity analysis using E-values to assess the threshold effect size of unmeasured confounders required to nullify the significant associations between inpatient alpha-1-blocker use and COVID-19 in-hospital mortality

Point estimate for OR Point estimate for HR

(Upper limit of CI) (Upper limit of CI)

Overall cohort, inpatient use

$1.83(1.25)$

$1.82(1.34)$

Hospital stay $>1$ day, inpatient use

$1.89(1.31)$

1.74 (1.23) 
medRxiv preprint doi: https://doi.org/10.1101/2021.04.08.21255148; this version posted April 11, 2021. The copyright holder for this preprint (which was not certified by peer review) is the author/funder, who has granted medRxiv a license to display the preprint in perpetuity. It is made available under a CC-BY-NC-ND 4.0 International license .

Table S3. Inverse propensity-weighted logistic regression for COVID-19 in-hospital mortality, by cohort (overall vs. hospitalization $>1$ day) and alpha-1-blocker exposure (any vs. inpatient use)

\begin{tabular}{lll}
\hline & Adjusted OR (95\% CI) & p-value \\
\hline Overall cohort, any exposure & $0.740(0.512-1.070)$ & 0.110 \\
Overall cohort, inpatient use & $0.630(0.424-0.935)$ & 0.022 \\
Hospital stay $>$ 1 day, any exposure & $0.760(0.520-1.110)$ & 0.157 \\
Hospital stay $>$ 1 day, inpatient use & $0.622(0.419-0.924)$ & 0.019 \\
\hline
\end{tabular}

